\title{
The Use of Concrete Ponds As a Medium to Spiny Lobster Rearing In Marine Aquaculture Installation Boncong, Tuban
}

\author{
$1^{\text {st }}$ Fani Fariedah ${ }^{1}, 2^{\text {nd }}$ Maulina Nela ${ }^{2}, 3^{\text {rd }}$ Ahmad Abtokhi ${ }^{2}$ \\ \{fanifariedah@ub.ac.id ${ }^{1}$ \} \\ Universitas Brawijaya, Fisheries and Marine Science Faculty, Malang, Indonesia ${ }^{1}$, Universitas Islam \\ Negeri Maulana Malik Ibrahim, Science and Technology Faculty, Malang, Indonesia ${ }^{2}$
}

\begin{abstract}
Lobster is an important economic species and is an export commodity. One of the marine lobsters that is the mainstay of the export market is the spiny lobster (Panulirus ornatus). This study aims to determine the effect of using concrete ponds to improve the survival rate of spiny lobsters. The stages in the spiny lobster maintenance activities include pond preparation, seed selection, water quality management, feeding management and pest and disease control. The survival rate of spiny lobster at the end of this study is $90 \%$.
\end{abstract}

Keywords: concrete pond; spiny lobster; rearing

\section{Introduction}

The high intensity of fishing and the large number of lobster fishermen caused a lack of management of the availability of lobster stocks in the waters. Lack of the information about the peak season of the lobster capture also causes fishing efforts in certain months to a decline in production [1].

According to Moosa (1984) in [2] that rock and sand lobsters are a type of crayfish (Panulirus spp.) Found in Indonesian waters because of the presence of good habitats in the form of coral reefs and coral reefs that thrive because of their tropical climate and have an average temperature of $28^{\circ} \mathrm{C}$. Tropical rock lobster, Panulirus ornatus, is a commercial coral lobster in the north-east Australia. Over the past decade, joint research and development in Australia has examined various stages of life history, specifically the complex and larval phases [3].

In recent years, the demand for marine commodities including lobster has continued to increase. Demand both for local consumption and for export, which is so high, makes fishermen intensively catch lobster. Catching lobsters from the wild and using feed in the form of trash fish is a pressure for lobster cultivation [4]. A high market value, increasing global demand, and concern for the sustainability of wild stocks have created significant interest in the development of spiny lobster aquaculture [5]. Seeing the importance of lobster commodities, including spiny lobster ( $P$. ornatus), a good rearing technique must be held to produce products according to consumer demand. Thus, the supply of lobster needs can also be met. Lobster aquaculture has been developed with the floating net cage system in the last three years in several coastal areas in Indonesia by requiring clear, calm and far from water 
pollution [6]. However, some regions in Indonesia do not all have waters that are suitable for lobster cultivation with floating net cage systems, so it needs to be studied to cultivate lobsters in controlled tanks as well as those that have developed in Australia and Vietnam with very high success [7].

\section{Methods}

This study held in June to September 2016 in Marine Aquaculture Installation Boncong, Tuban. This study was descriptive qualitative starting with pond preparation, seed selection, water quality management, feeding management and pest and disease control. This study was contain from four stages that is pond preparation, seed selection, feeding management, and water quality management.

\subsection{Pond Preparation}

Activities carried out before rearing, should prepare the pond first. This is because the ponds that are used must be clean and free of pests and other impurities which attached to the floor and walls of the pond. The next step is to dry the pond and fill the pond with $45 \mathrm{~cm}$ of sea water.

Ponds for rearing activities for lobster spinys are made of concrete and rectangular (Fig. 1). The size of each pool is $2.5 \times 1 \times 1 \mathrm{~m}$ with a thickness of $16 \mathrm{~cm}$. Have an outlet with a diameter of $8 \mathrm{~cm}$. Inlet pipe diameters of $2.5 \mathrm{~cm}$. The pool is equipped with an aerator with an air pipe with a diameter of $2.5 \mathrm{~cm}$. each pond is stocked with a density of 60 lobsters.

\subsection{Seed Selection}

Seeds are obtained from collectors. The selection is done in the form of complete body parts. The Characteristics of a good seed that is not deformed and complete limbs. In addition, salinity adaptation was carried out for 1 week by reducing salinity. Seed weight is usually less than $100 \mathrm{~g}$ with a body length of $8-10 \mathrm{~cm}$. Seeds are maintained for 3 months until they reach a consumption size of 300 grams.

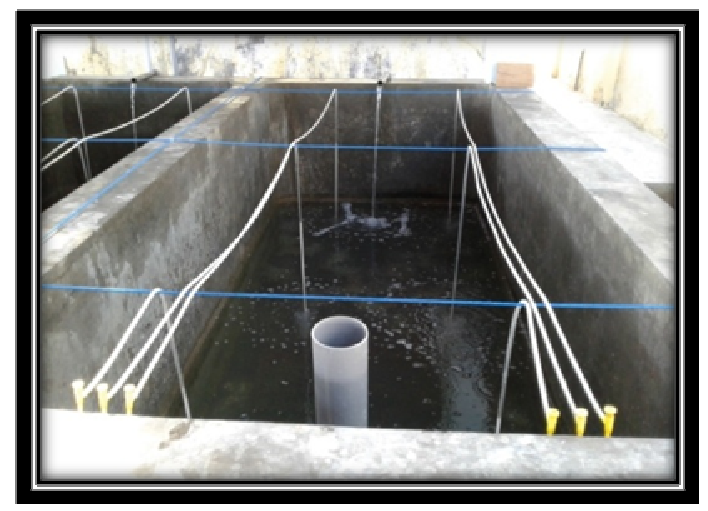

Figure 1. Concrete Ponds construction

\subsection{Feeding Management}


The main feed of seeds and adult lobsters should be from the bivalves, but because the procurement is difficult, it is replaced with trash fish cut into small pieces and do not use pellets as said by Smith et al (2003) in [8] that lobster growth is better when using fresh fish feed than using pellets. The use of trash fish instead of bivalves in accordance with what is stated by [9] that lobster tends to be carnivorous so it will grow better if fed with animal protein. Feeding rate is $10-15 \%$ of lobster body weight. The most feed is given at night because lobsters are nocturnal and to avoid cannibalism. Reference [10] stated that cannibalism is the nature of eating each other, in this case a lobster.

\subsection{Water Quality Management}

Management of the water quality in lobster rearing activities include of temperature measurement, dissolved oxygen (DO), and salinity. These parameters will affect the body's metabolic processes, such as the activity of looking for feed, digestion, and shrimp growth. Measurements are made at $07.00 \mathrm{WIB} ; 12.00 \mathrm{WIB}$; and 17.00 WIB. The measurement aims to determine the fluctuation of water quality.

\section{Result}

The time needed to reach a size of $300 \mathrm{~g}$ /individual of a size of $100 \mathrm{~g} /$ individual is usually between 3-4 months. The larger the seedlings stocked, the faster the lobster harvest will be. Survival rate (SR) is less than $90 \%$, meaning that in one pond with 60 stocking densities that survive were 54.

The results of measurements of water temperature at $07.00 \mathrm{WIB}$ have a range of $26^{\circ} \mathrm{C}$ $28.9^{\circ} \mathrm{C}$; at $12.00 \mathrm{WIB}$ it had a range between $27.9^{\circ} \mathrm{C}$ to $29.9^{\circ} \mathrm{C}$; at $17.00 \mathrm{WIB}$ it had a range of $27.4^{\circ} \mathrm{C}-29.5^{\circ} \mathrm{C}$ (Table 1). The temperature range is still in normal conditions. The changes are also not too significant.

The results of dissolved oxygen (DO) measurements in the morning at $07.00 \mathrm{WIB}$ have a range of values between 5.5-7.9 ppm; at noon at 12.00 WIB has a range between 5.5-8.4 ppm; and in the afternoon at 5:00 p.m. WIB has a range of 6.0-7.6 ppm (Table 1). The range of dissolved oxygen values (DO) is still in normal conditions.

Salinity measurement results in the morning at $07.00 \mathrm{WIB}$ have a range of values between 30-36 ppt; at noon at $12.00 \mathrm{WIB}$ has a range of values between 27 to $36 \mathrm{ppt}$; and in the afternoon at 17.00 WIB has a range of values between 29 to 35 ppt (Table 1). The salinity range is suitable for spiny lobster cultivation.

$\mathrm{PH}$ measurement results in the morning at $07.00 \mathrm{WIB}$; noon at $12.00 \mathrm{WIB}$; and in the afternoon at 17.00 WIB has the same value range between 6-8 (Table 1). The pH value for sea lobster tends to be alkaline and the value is suitable for live media of spiny lobster. In this study no lobster was found to be affected by the disease. This can be known by the absence of mass deaths in the rearing cycle.

Table 1. Water Quality In Rearing Pond Of The Spiny Lobster (Panulirus Ornatus)

\begin{tabular}{cccc}
\hline $\begin{array}{c}\text { Paramete } \\
\text { r }\end{array}$ & $\mathbf{0 7 . 0 0}$ & $\mathbf{1 2 . 0 0}$ & $\mathbf{1 7 . 0 0}$ \\
\hline $\begin{array}{c}\text { Temperatu } \\
\text { re }\end{array}$ & $\begin{array}{c}26^{\circ} \mathrm{C}- \\
28,9^{\circ} \mathrm{C}\end{array}$ & $\begin{array}{c}27,9^{\circ} \mathrm{C}- \\
29,9^{\circ} \mathrm{C}\end{array}$ & $\begin{array}{c}27,4^{\circ} \mathrm{C}- \\
29,5^{\circ} \mathrm{C}\end{array}$ \\
\hline
\end{tabular}




\begin{tabular}{cccc}
\hline DO & $\begin{array}{c}5,5-7,9 \\
\text { ppm }\end{array}$ & $\begin{array}{c}5,5-8,4 \\
\text { ppm }\end{array}$ & $\begin{array}{c}6,0-7,6 \\
\text { ppm }\end{array}$ \\
\hline Salinity & $30-36 \mathrm{ppt}$ & $27-36 \mathrm{ppt}$ & $29-35 \mathrm{ppt}$ \\
\hline $\mathrm{pH}$ & $6-8$ & $6-8$ & $6-8$ \\
\hline
\end{tabular}

\section{Discussion}

The high survival rates due to the low levels of stress experienced by lobsters when kept in concrete ponds rather than maintained in floating net cages. The stress response in the lobster can be caused by several things including environmental factors, handling and bacterial infections [11]. Stocking density is closely related to growth and survival rates. The height of lobster stocking is a factor that determines the success of cultivation. Lobster with low stocking density has a great opportunity to get the part of food that is around it, besides that there are also fewer competitors around it. This will provide more space for lobsters to move and grow and develop [12].

According to [13] that Feed from spiny lobster (P. ornatus) is usually in the form of shellfish or can also use trash fish cut into small pieces. Food is given regularly every day. Feeding should pay attention to the nocturnal nature of lobster. The best feed should be given at night to be more effective. According to [14] that cannibal is a trait that likes to prey on its own type. High mortality rates in lobsters are usually due to cannibalism. Cannibalism is at its peak when other lobsters experience moulting and also lack of feed. Cannibalism in spiny lobsters often occurs at night. The main prey is lobster, which is new. The new lobster is hardpressed, for the hardened carapace it takes quite a long time to make it easy to attack because the meat is still soft. Efforts made to prevent cannibalism are by sending lobsters which will be difficult. In addition, high feeding frequency can also prevent predation on lobster seizures.

The quality of water in open fisheries fluctuates more frequently than in concrete ponds so that the water quality in the maintenance pond looks stable and is in the normal range. According to Subani (1981) in [2] stated that rock and sand lobsters are a type of crayfish (Panulirus spp.) found in Indonesian waters because of the presence of good habitat in the form of coral reefs that thrive because of their tropical climate and have an average temperature of $28^{\circ} \mathrm{C}$. In accordance with [15] statement that the temperature range which tends to be stable will not make lobsters experience interference in adaptation to environmental changes so that it is beneficial in utilizing energy for metabolism and growth.

Ahmad et al., (1991) in [16] stated that dissolved oxygen is the most critical parameter in fish farming. Solubility of oxygen in the water is affected by temperature, salinity and air pressure. Increased temperature, salinity and pressure cause a decrease in oxygen, and vice versa. For the benefit of fish farming, optimal dissolved oxygen ranges from 5-8 mg/l.

Reference [17] stated that salinity are an important factor to support the rearing of spiny lobster. Growth was highest in 35 ppt salinity and progressively reduced at lower salinities [18]. Water salinity usually ranges from 30-35 ppt, but this contrasts with research conducted by [19] that at a salinity of $35 \mathrm{ppt}$, the survival of lobster will decrease due to high cannibalism in that salinity. 
Ahmad (1991) in [7] said that explained that to be able to live and grow well, aquatic organisms (fish and shrimp) require a medium with a $\mathrm{pH}$ range between 6.8-8.5. According to [20] that $\mathrm{pH}$ value within the range of 7.07-7.86 was still supported the life of $P$. homarus juvenile.

In addition, lobster rearing activities have also just been pioneered so there have been no pest or disease problems. It was just that the level of cannibalism makes lobsters die, but not how much. There were no symptoms of disease found on the lobster which were raised because the learning was done by selecting seeds using a salinity test and well-scheduled feed management, namely the largest percentage is given at night to avoid cannibalism. Normally cannibalism occurs because less feed and also lobsters that have just been moulting will be the main target for other lobsters.

\section{Conclusion}

Maintenance of spiny lobsters which carried out using concrete ponds can produce a high survival rate of $90 \%$. High life support is supported by good feed management and proper water quality control.

Acknowledgements. This paper in conjuction with the 9th International Conference On Green Technology (ICGT) 2018

\section{References}

[1] Bakhtiar, M.N., A. Solichin dan S.W. Saputra. 2013. Pertumbuhan dan laju mortalitas lobster batu hijau (Panulirus homarus) di perairan cilacap jawa tengah. Diponegoro Journal Of Maquares. 2(4): $1-10$

[2] Fauzi, M., A.P. Setyo, I.T. Hargiyanto, F.S. Satria dan A.A. Utama. 2013. Hubungan panjangberat dan faktor kondisi lobster batu (Panulirus penicillatus) di perairan selatan gunung kidul dan pacitan. Bawal. 5(2): 97-102.

[3] Sachlikidis, N.G., C.M. Jones and J.E. Seymour. 2010. The effect of temperature on the incubation of eggs of the tropical rock lobster Panulirus ornatus. Aquaculture. 305: 79-83.

[4] ACIAR. 2009. Panen dari pasar lobster; Proyek: Meningkatkan Pertumbuhan dan Pakan Lobster di NTB dan NTT. Indonesia Newsletter, Australian Center for International Agricultural Research.

[5] Solanski, Y., K.L. Jetani, S.I. Khan, S.A. Kotiya, N.P. Makawana and A.M. Rather, 2012. Effect of stocking density on growth and survival rate of spiny lobster (Panulirus polyphagus) in cage culture system. Int. J. Aquat. Sci., 3: 3-14.

[6] Yuliani.H.. 2010. Studi pengaruh pemberian jenis pakan yang berbeda terhadap survival rate post puerulus lobster pasir (Panulirus homarus) Pada Fase Nursery.[Skripsi, unpublished]. Universitas Mataram.

[7] Cokrowati, N., P. Utami dan Sarifin. 2012. Perbedaaan padat tebar terhadap tingkat pertumbuhan dan kelangsungan hidup post peurulus lobster pasir (Panulirus homarus) pada bak terkontrol. Jurnal Kelautan. 5(2): 156-166.

[8] Rathinam, A.M.M., D. Kandasami, Joe K. Kizhakudan, V. A. Leslie and A. D. Gandhi. 2009. Effect of dietary protein on the growth of spiny lobster Panulirus homarus (Linnaeus) J. Mar. Biol. Ass. India, 51(1) : $114-117$ 
[9] Masangkil, L., Indra, R.N. S., Cyska Luminta. Pengaruh perbedaan jenis pakan terhadap pertumbuhan lobster laut, Panulirus versicolor. Jurnal Budidaya Perairan. Vol. 5 No. 3:1-10. Universitas Sam Ratulangi. Manado 2017.

[10] Priyambodo B., Arfiyanto A., Libuh, Sujangka A., Tahang M.,Wildan. Petunjuk teknis budidaya lobster (panulirus spp) teknik pengumpulan benih, pembesaran dan transportasi. Kementerian Kelautan dan Perikanan, Direktorat Jenderal Perikanan Budidaya, Balai Budidaya Laut Lombok 2011.

[11] Lorenzon S., Martinis M., Borme D., Ferrero E. A., Hemolymph parameters as physiological biomarkers for monitoring the effects of fishing and commercial maintenance methods in Squilla mantis (Crustacea, Stomatopoda). Fisheries Research 137:9-17 2013.

[12] Sya'roni. M. Pengaruh perbedaan padat tebar terhadap tingkat pertumbuhan post puerulus lobster pasir (Panulirus homarus) pada fase nursery. [Skripsi, unpublished]. Universitas Mataram 2010.

[13] Tim Perikanan WWF-Indonesia. Perikanan lobster laut, panduan penangkapan dan penanganan edisi I. WWF-Indonesia: Jakartam 2015.

[14] Lukito, A dan S. Paryugo. panduan lengkap lobster air tawar. Penebar Swadaya: Jakarta, (2007).

[15] Akbar, D. 2008. Upaya peningkatan produktivitas pendederan lobster air tawar Cherax quadricarinatus pada berbagai kepadatan dalam akuarium dengan lantai ganda, serta penerapan sistem resirkulasi. [Skripsi]. Departemen Budidaya Perairan, Fakultas Perikanan dan Ilmu Kelautan, Intitut Pertanian Bogor

[16] Affan, J.M. Identifikasi lokasi untuk pengembangan budidaya kerambajaring apung (KJA) berdasarkan faktor lingkungan dan kualitas air di perairan pantai timur bangka tengah. Depik. 1(11): 78-85 2012.

[17] Mustafa, A. Budidaya lobster (Panulirus sp.) di vietnam dan aplikasinya di indonesia. Media Akuakultur . 8(2): 73-84 2013.

[18] Vidya, K and Shoji, Joseph. Effect of salinity on growth and survival of juvenile Indian spiny lobster, Panulirus homarus (Linnaeus). Indian Journal of Fisheries 59 (1) 2012.

[19] Jones, Clive M. Temperature and salinity tolerances of thetropical spiny lobster, Panulirus ornatus. Journal of The world Aquaculture Society, 40 (6): 744-752 2009.

[20] Adiyana K. Evaluation of spinny lobster Pannulirus homarus physiology responsse on different shelters reared in recirculated system. MSc thesis, Institut Pertanian Bogor, Indonesia, 2014. 